\title{
FEHÉR KRISZTINA: A nyelv grammatikája. A nyelvtudomány és a kognitív
}

pszichológia határán. Debrecen, Debreceni Egyetemi Kiadó, 2018. (394 lap)

1. A nyelvről való tudás rendszerezését mindig is meghatározó feladatnak tekintették a tudásépítő közösségekben. Az ókortól kezdve a modern nyelvtudomány kialakulásán át folyamatosan formálódott és formálódik a mai napig az az igény, hogy hogyan lehet a természetes úton elsajátítható nyelvekről olyan ismereteket kialakítani, amelyek a nyelvhasználó közösségek számára hasznosnak bizonyulnak. Amikor valaki arra vállalkozik, hogy ennek a rendkívül összetett emberi jelenségnek rendszerszerü leírását adja, akkor következésképpen választás elé kerül: meg kell határoznia saját viszonyát a nyelvhez. Ez a viszony pedig kijelöli az alapvető irányt a nyelvleírás útján.

Fehér Krisztina A nyelv grammatikája címü munkájában bemutatja a különböző nyelvleírási irányokat, alaposan körbejárja a lehetőségeket, felhívja a figyelmet az akadályokra, hogy végül határozott iránymutatást adjon az olvasónak. A strukturalizmusra épülö, valamint a generatív és posztgeneratív irányzatok formalizáló szemléletével szemben a funkcionális és a társasnyelvészettel érintkező kognitív nyelvészet közelítésmódjára irányítja rá a figyelmet a szerző. Ez a kétféle nyelvészeti hagyomány merőben más úton közelít a nyelvhez, és ennek megfelelően lényegien más oldaláról mutatja be azt. A formalizálásra törekvő irányzatok felfogásában a szabályokkal, bináris és zárt kategóriákkal leírható nyelv modulárisan részekre bontható, amelyek hierarchikusan épülnek egymásra. A kognitív közelítésmód szerint ezzel szemben a valószínüségi adatok alapján modellálható hálózatos nyelv egymással kölcsönös viszonyban lévő elemek kontinuumából alakul ki a viszonyok dinamikus formálódásával.

A szerző ez utóbbi megközelítést az egyes tudományterületek — nevezetesen a nyelvtudomány és a kognitív pszichológia —, valamint a nyelvészeti részterületek - a szociolingvisztika és a pszicholingvisztika, a fonetika és a fonológia — eredményeinek szintetizálására alapozva jelöli ki. A munka vállaltan törekszik a területek közötti párbeszéd megteremtésére és erősítésére, ezáltal termékenyítőleg kíván hatni a grammatikaírásra. Fehér Krisztina ezen törekvését már korábban is jelezte a kutatómunka részeredményeiről publikált számos tanulmánya. Az interdiszciplináris szemlélet eredményeként azonban nem egyfajta taxonomikus grammatikát dolgozott ki a szerző, hanem sokkal inkább egy olyan elméletileg és módszertanilag megalapozott koncepciót vázolt fel, amely kiindulópontot jelenthet a nyelvtanírás számára. Ehhez a szerző ugyan korábbi munkák eredményeire támaszkodik, mégis elmondható, hogy e vizsgálatok áttekintésének szisztematikussága, illetve a pszicholingvisztikai és fonetikai kísérletek, 
továbbá a korpuszelemzések eredményeinek közös keretbe ágyazása újabb lényegi szempontokat világít meg a nyelvleírás gyakorlatában. Ebben a tekintetben a könyv megállapításait azonban tovább árnyalhatta volna, ha szerzője még szervesebben kapcsolódik a funkcionális és kognitív nyelvelméleti munkákhoz (pl. HALLIDAY 1978, 1994, LANGACKER 1987, 2008, BYBEE 2010), és explicit módon fogalmazza meg a hozzájuk füződő viszonyát.

A könyv fejezetei sokféle témakört tárgyalnak, amelyek látszólagos különbözőségük ellenére koherens gondolatmenetbe épülnek be. Az első fejezetek tudománytörténeti áttekintésében a szabály és analógia értelmezése kerül középpontba, valamint ezzel összefüggésben az algebrai és a statisztikai tanulást veti össze a szerző. A statisztikai megközelítésre támaszkodva a skalaritás fogalmának bevezetése egy átmenet-valószínüségeken alapuló nyelvtani koncepciót vetít elöre. Ezt követik a könyv azon részei, amelyek módszeresen elemzik a formális nyelvtani leírásokkal kapcsolatban felmerülö kérdéseket a kognitív pszichológia területén végzett kísérletek tükrében. A formalizálás nyomán jelentkező nehézségek áttekintését követően a szerző a lexikon, a morfológia és a fonotaxis statisztikai alapú leírásának lehetőségét mutatja be a munka következő fejezeteiben. A könyv második fele a hangtani vizsgálatokra fókuszál: a fonológia, fonetika, dialektológia és kognitív pszichológia eredményeinek bevonásával válnak meghatározhatóvá a szótagalkotó hangkombinációk a beszédpercepció alapegységeiként. Végül a nyelv hangzós tulajdonságainak kiemelt szerepére tekintettel a prozódia-fonotaxis-lexikon-morfológia-szintaxis kontinuumát felölelő dinamikus hálózatnyelvtan ismertetésével zárul a munka. A bemutatott statisztikai nyelvtani hálózatmodell erénye, hogy nemcsak az elméleti keretek összehangolásának eredményeképpen jött létre, hanem a hozzá társuló módszertanban is ötvöződnek a kognitív pszichológia kísérletes megközelítései a korpuszvizsgálat lehetőségeivel.

A kognitív tudományi és nyelvészeti területek elméleti és módszertani apparátusának egymásra vonatkoztatásával az emberi megismerést, a nyelvhasználat tényeit és az empíriát a középpontba állító munka e közelítésmódjával illeszkedik a nyelvtudomány nemzetközi gyakorlatához. Ezt jelzi a könyv gazdag szakirodalomjegyzéke is.

2. Fehér Krisztina könyvének legfőbb tézise, hogy „,a nyelvtan nem más, mint maga a nyelvi müködés" (15). Ebből a Humboldtra visszavezethető gondolatból következik, hogy egyrészt a nyelvtan minden nyelvi jelenség együttes rendszerét magában foglalja, másrészt pedig hogy a nyelv müködése teljes folyamatában az egyes egyének nyelvelsajátításától a generációkon át tartó nyelvhasználaton keresztül - értelmezhető. Egy ilyen rendszert az egyének mentális tevékenysége mellett a társas interakciók szerveznek, és ebből adódóan eredendően sajátja lesz a változatosság és a változás. Ennek megfelelően a szerző a nyelvtant a társas 
interakciók során elsajátítható és müködtethető rendszerszerü tudásnak tekinti. Egy ilyen nyelvtan a kontinuumelvnek megfelelően nem von éles határt a fonológia, a morfológia, a lexikon és a szintaxis között, mivel a nyelvtani szerkezeteket a hangkapcsolatok különböző komplexitású megjelenéseiként azonosítja. A nyelvleírás hatókörét a prozódia-fonotaxis-lexikon-morfológia-szintaxis kontinuumával jelöli ki a szerző, melynek jellegét a szociolingvisztika és a pragmatika szemléletmódja határozza meg. Ez azt jelenti, hogy a nyelvi szerkezetek és azok jelentései csak a társas interakciókban kialakuló kontextus révén határozhatók meg. Az ilyen típusú funkcionális megközelítések az általános elméleti megállapításokat az empirikus megfigyelések tükrében sorozatosan vizsgálják, vagyis az elméleti tételek és az empirikus adatok folyamatos kölcsönhatásában formálódik a leírás kerete. Egy funkcionális modell ebböl adódóan nem vállalkozhat a nyelv teljes és végérvényes leírására: nem állhat ugyanis rendelkezésére minden adat a teljesnek tekinthető leírásához, mivel eredendően változónak tekinti a vizsgált jelenséget. Ezzel összefügg, hogy a nyelvi leírásban nem a megjósolhatóság, hanem a valószínüsíthetőség lesz az elsődleges szempont. A leírás keretét tehát úgy szükséges kijelölni, hogy ezekhez a jellemzőkhöz illeszkedjen.

Ebből a szempontból a nyelvi rendszer leírásában két különböző elv figyelhető meg a nyelvtudományban: a szabály és az analógia. A könyv első fejezetei arra mutatnak rá, hogy a nyelvtudomány történetét áttekintve érdemes a két fogalom meghatározását végiggondolni: míg a szabályt olyan absztrakt formulának lehet tekinteni, amelybe a maradéktalanul megfeleltethetö nyelvi elemek helyettesíthetők csak be, addig az analógiának azt a tulajdonságát célszerű kiemelni, hogy skálaszerü értékekkel jellemezhető. A nyelv leírását szabály alapon megközelítő irányzatok — tekintettel a szabály kategorikusan merev voltára — nehezen alkalmasak a különböző formákban megjelenő nyelvi változatosság és a nyelv változásában tetten érhető folyamat jelleg megragadására. Az analógia ezzel szemben hasonlósági alapon valószínúsíti a kapcsolatokat, emiatt statisztikai szempontból fokozatiságot feltételez.

3. Az analógianyelvtan koncepcióját a szerző empirikus módszerrel végzett vizsgálatok - kognitív pszichológiai tesztek — eredményeire alapozza. Ehhez a nyelvelsajátítás kérdésében az algebrai és a statisztikai tanulás összehasonlítása jelentett kiindulópontot. Az algebrai tanulás ugyanis ebből a szempontból a bináris választáson alapuló szabálynyelvtan koncepcióját erősíti, a statisztikai tanulás átmenet-valószínüségeket feltételező mechanizmusa viszont az analógianyelvtanét. Ez azzal magyarázható, hogy az algebrai tanulás absztrakt összefüggéseken alapuló szabályokra épít, amely szabályok egyértelmủ megfeleltetéseket eredményeznek, és általános érvénnyel bírnak. Chomsky innátista koncepciója szerint ezeknek az absztrakt szabályoknak a felismerése genetikailag van kódolva, tehát egy előre programozott nyelvelsajátító eszköz, egy nyelvi modul felel azért, hogy 
a nyelvek összességére érvényes univerzális szabályokat vonatkoztatni tudják a gyerekek a nyelvelsajátítás folyamán saját kiépülő nyelvükre. Ez az elgondolás egyben feltételezi, hogy egy univerzális grammatikában a nyelvtani kategóriák apriorinak és abszolút azonosíthatónak tekinthetők. A statisztikai tanulás ezzel szemben az észlelt adatokból meghatározható átmenet-valószínüségekre helyezi a hangsúlyt, ezáltal fokozatiságot tételez fel. Korábbi kutatásokra támaszkodva a nyelvelsajátítás folyamatában a gyerek általános kognitív képességei és kapacitása mellett a szociális környezet szerepét is figyelembe veszi a gyerek nyelvi fejlődésében. Az egyéni képességek és a környezeti hatások eltérő mértéke változatos és változó nyelvi tudást eredményez. Ahogyan arra a szerző rávilágít, a témában folytatott kísérletek módszertanára és eredményeire való tekintettel nem lehet kétséget kizáróan cáfolni a nyelvtannak sem a statisztikai, sem az algebrai alapú elsajátítását. Mivel a kísérletek között nem volt olyan, amely grammatikai struktúrák statisztikai korrelációktól mentes tanulását példázná, ugyanakkor arra van példa, hogy az emberek az elemek közti átmenet-valószínüségekkel jellemezhető nyelvtant sajátítsanak el, ezért a statisztikai tanulás lehetőségével mindenképpen érdemes számolni.

A nyelvelsajátításra vonatkozóan — ezen belül a nyelvi fejlödés szempontjából lényeges szószegmentáció kérdésében — érdemes továbbá említést tenni a hangsúlyhelyek prozódiai jellemzőinek szerepéröl a szóhatárok kijelölésében. E szerint a megközelítés szerint a csecsemők a hangsúlyos szótagokat úgy kezelhetik, hogy azok egy új nyelvi egység kezdeteként funkcionálnak. Az elképzelésről laboratóriumi körülmények között az derült ki, hogy a csecsemök kezdetben valóban a hangsúlyhelyeket tekintik elsődleges támpontoknak, majd a prozódiai szegmentációból adódó tévedéseket a nyelvelsajátítás során később korrigálják. A hangsúlyalapú szegmentációról azonban ugyancsak elmondható, hogy statisztikai jellegü, ugyanis a hangsúlyos és hangsúlytalan szótagok ritmikus váltakozása kombinatorikus mintázatot eredményez. A prozódiai és a fonotaktikai mintázatok szegmentálhatósága között nem szembenállást kell feltételezni tehát, hanem olyan átmenetet, amelyben a prozódiai szerkezetek durvábban, a fonotaktikai struktúrák finomabban tagolhatók elemeikre. Ez a nyelvelsajátítás szempontjából azt jelenti, hogy a csecsemők a nyelvi tapasztalat bővülésével a kezdeti, nagyobb statisztikai (prozódiai) mintázatokat azok belső (fonotaktikai) szerkezeteikként elemzik tovább. Összességében megállapítható, hogy a szerző a tanuláselméletek közül a nyelvelsajátításban is lényegi szerepet betöltö átmenet-valószínüségeken alapuló statisztikai tanulás mellett érvel, ami összhangban van a nyelvi folyamatok kontinuumaként értelmezhető analógianyelvtan koncepciójával.

4. A nyelvelsajátítás tanulmányozása révén egyértelmủen megállapítható, hogy a hangtani jellemzők feldolgozásának kiemelt szerepe van az egyén nyelvi 
fejlődésének folyamatában, a munka ezzel együtt pedig arra is rámutat, hogy a nyelv általános müködésének feltérképezése szempontjából is érdemes hangsúlyt fektetni a prozódiai és fonotaktikai jelenségekre. A nyelveket prozódiai szempontból — a ritmikai szerkezetük alapját képező egységnek megfelelően - a hangsúlyalapú, a szótagalapú és a moraalapú nyelvek kategóriáiba szokás besorolni. A szerző azonban rávilágít arra, hogy az empirikus adatok fényében ez a kategorizálás nehézségekbe ütközik: például bizonytalan a francia vagy a spanyol nyelv szótagalapúsága, valamint kérdéses a japán egyértelmü moraalapúsága, illetve problémát jelent a finn besorolása. Minderre megoldás lehet, ha olyan tipológiai rendszert alkalmazunk, amely a beszédfolyamban előforduló magán- és mássalhangzók arányát veszi figyelembe, pontosabban az egy magánhangzó után átlagos időközönként megjelenő újabb magánhangzót. A magán- és mássalhangzók feltűnésének időszerkezetére épülő rendszer szerint az egyes nyelvek egymáshoz képest egy kontinuumon helyezhetők el, szemben a hagyományos megközelítés zárt kategóriaosztályaival. A szerző emellett felhívja a figyelmet arra, hogy a tipológiai rendszer tovább pontosítható, ha a nyelveket szótag alapon rendszerezzük. Ez esetben a korábban szótagalapúnak tekintett nyelvekben az egy szótagnyi egység, a hangsúlyalapú nyelvekben a hangsúlyos szótag és az azt követő hangsúlytalan szótagok együttese izokrón, a moraalapú nyelvekben pedig az azonos moraszámú szótagok időtartama egyforma. Ennek a rendszernek a szótag képezi az alapját a következő meghatározással: szótagnak tekinthetjük ,azon szótagmagot alkotó hangokat (jellegzetesen magánhangzókat, illetve bizonyos nyelvekben ritkábban nagy hangzósságú mássalhangzókat), illetve azon szótagmaggal rendelkező hangkombinációkat, amelyek a beszédpercepció közvetlen egységeiként szolgálnak" (291). Ez a definíció összhangban van az anyanyelv fonotaktikai mintázatainak átmenet-valószínüségekkel történő felismerésével, amely a beszédpercepció során magánhangzók és hangkombinációk gyakoriságiszomszédsági eloszlásának azonosításával megy végbe. Összegezve megállapítható, hogy a gyakorisági eloszlások mentén alakuló átmenet-valószínüségek nyelvtöl függetlenül szerepet játszanak a nyelvi rendszer müködésének irányításában, a nyelvek tipológiája pedig egy ezzel a folyamattal összehangolható szótagalapú rendszerre épülhet.

5. A könyv a nyelvek közötti azonosságok és különbségek megállapítása mellett, a nyelvek rendszerének leírásában is a gyakorisági mutatók vizsgálatára támaszkodik a lexikon, a morfológia és a fonotaxis területén egyaránt. Ebböl következően a vázolt nyelvtani modell érzékeny a változásra és a változatosságra is. A lexikon területén például a lexikai egységek kijelölése szempontjából fontos kérdés a szavak határainak megállapítása. Az átmenet-valószínüségeken alapuló modell erre nem azzal a kérdéssel keres választ, hogy „mi a szó?”, hanem a „mi egy szó?” kérdést teszi fel. A válasz pedig azon a megállapításon alapul, 
hogy két szomszédos szó esetében a szó belseji együttjárási-gyakorisági mutatók magasabbak az első szó vége és a második szó eleje között lévőknél, ami azt jelenti, hogy egy-egy szó azonosítása a szóvégek és a szókezdetek közötti alacsonyabb átmenet-valószínüségek alapján történik. A szerző ezzel együtt azt is kiemeli, hogy mivel az emberek különféle nyelvi tapasztalatokat szereznek, ezért a hangsorok együttjárási-gyakorisági mutatói személyenként eltérhetnek, vagyis a rendszer az adatok függvényében dinamikusan változhat. A szóhangalakok statisztikai azonosításának lehetősége felveti továbbá, hogy a szóelemek (tövek, toldalékok) esetében is hasonló gyakorisági mutatók müködnek, azaz a szóalakok tövei és toldalékai között lévő átmenet-valószínüségek is jelentősebb eltérést mutatnak, mint a tövek és a toldalékok hangtestén belüliek. Egy ilyen statisztikai morfológia nem más, mint egy hangsorszerkezeti (fonotaktikai) alapú morfológia amelyben az elemzés alapegységei a hangkapcsolatok - , ugyanis az egyes szavak hangsorrészletei közti átmenet-valószínüségek fogják kijelölni, hogy az adott szóalakok milyen morfológiai mintázatokkal jellemezhetők. A gyakorisági-együttjárási mutatók függvényében különböző korpuszokban és eltérő időben más-más lehet a mintázat, vagyis egy-egy szóalakhoz többféle, dinamikus morfológiai struktúra társítható, amelyek egymáshoz képest eltérő hangalakú és számú szóelemeket tartalmaznak. A statisztikai morfológia ennek alapján az alaktani változatokról és a változási folyamatokról nem bináris, hanem skaláris modell keretei között adna számot, aminek így szerves részét képezik például a tövek és a toldalékok közti átmenetek. Az elhangzó hangsorok elemzésére épülő átmenet-valószínüségi morfológiának persze tekintettel kell lennie a koartikulációra is, mivel a beszédpercepció során ezeknek a statisztikai információit lehet feldolgozni.

E felfogás értelmében a morfoszintaktikai mintázatok a fonotaktikai struktúrákon keresztül alakulnak ki, azaz a fonotaxis, a lexikon, a morfológia és a szintaxis voltaképpen egyazon nyelvtani jelenség kontinuumaként értelmezhető. Mindent együttvéve úgy tünik, hogy a szerző által bemutatott, a nyelvhasználatból származó adatokra épülő statisztikai nyelvtan dinamikus keretként képes modellálni a nyelvet, annak változatosságával és változásával összhangban.

6. A statisztikai nyelvtan skalaritásának és kontinuum jellegének - a modulárissal szemben - a hálózatos szerveződés felel meg. A szerző a hálózatot nemcsak az emberi elme nyelvtanának hatékony modellezésére tartja alkalmasnak, hanem a nyelvi rendszer társas vonatkozású reprezentálására is, azaz emberek közötti viszonylatok feltérképezésére. A statisztikai analógianyelvtan valószínűségi, szomszédossági és gyakorisági mintázatai a nyelvi tapasztalatok függvényében alakulnak, vagyis az emberek közötti kommunikációs kapcsolatok határozzák meg, hogy az egyes személyek milyen nyelvi elemekkel és milyen gyakran találkoznak. Ez azt jelenti, hogy nemcsak az egyén mentálisan szerveződő nyelvi rendszere, hanem az elmék interakciójával kialakuló nyelvi 
viszonyrendszer is dinamikus hálózatot alkot. A mentális nyelvtanok olyan kognitív hálózatként múködnek, amelyekben a nyelvi elemek a csúcspontok, s a nyelvi elemek közötti kapcsolatok a csúcspontokat összekötő éleknek feleltethetők meg. A mentális nyelvtanok pedig szociális hálózatba szerveződnek, amelyekben az egyes emberek elméjének nyelvtani rendszerei a csúcspontok, és a köztük lévő kapcsolatok az ezeket összekötő élek. Ahogyan a két rendszer egymásba ágyazódik, úgy áll egymással kölcsönhatásban is, azaz az egyének mentális nyelvi hálózatai kölcsönösen formálódnak a társas nyelvi interakciókkal. A szerző végső konklúziója ebből adódóan az, hogy a kognitív nyelvtanhálózatok müveletei csak társas közegükben, a társas nyelvi hálózatok folyamatai pedig csak kognitív kontextusukkal együtt ragadhatók meg.

7. A szerző a hálózatmodell és az analógianyelvtan közös alkalmazhatóságát hangsúlyozza, mivel a statisztikai tanulás valószínüségi, szomszédsági és gyakorisági mintázatainak változó és változatos természetéhez így megfelelő modell kínálkozik. Az analógia és a hálózat fogalmával kapcsolatban azt a közös jellemzőjüket lehet kiemelni ugyanis, hogy mindkettő hasonlósági alapon feltételezi a kapcsolatokat az egyes elemek között. Ebböl pedig az is következik, hogy a hasonlóság mértéke szerint a kapcsolatok eltérő erősségüek lehetnek, tehát a rendszer kategóriáit fokozatiság alapján lehet meghatározni, és ennek megfelelően besorolni azokba az elemeket. Eszerint egy hálózatban a gyakoribb, prototipikusabb elemek több kapcsolattal rendelkeznek, ami megfelel annak, hogy a gyakrabban együtt előforduló és magasabb átmenet-valószínüségekkel kapcsolódó nyelvi elemek között erősebb kognitív kapcsolattal kell számolni. A kevésbé gyakori, periférikus elemek viszont kevesebb kapcsolattal ágyazódnak be a hálózatrendszerbe, ami analóg azzal, hogy a ritkábban megjelenő és kisebb átmenetvalószínűséggel rendelkező elemkombinációk tagjainak esetében gyengébb kapcsolatokra számíthatunk. Ennek megfelelően a nyelvtan hálózatmodellje képes követni a változásokat, azaz a kapcsolaterösségek módosulását a nyelvi tapasztalatok függvényében, továbbá természetes tulajdonsága a változatosság is, tehát egyidejüleg többféle grammatikai változatra kiterjedhet. Az analógia egy ilyen nyelvtani koncepcióban az egyes elemek közötti viszony magyarázatára alkalmazható elv lehet, a hálózat pedig az elemek együttes rendszerének szerveződését modellálja. Ebböl következően pedig a „[h]álózatmodellel számolva a grammatika csakis egyféleképpen, méghozzá a legtágabban értelmezhető: a nyelv müködésének hogyanja nem lehet más vagy kevesebb annál, mint a nyelv, a maga teljességében" (339).

8. Mindent összevetve A nyelv grammatikája sikeresen teljesíti azt a kitüzött célt, hogy a különböző nyelvtudományon kívüli és belüli területek között párbeszédet teremtsen a nyelvleírás elméleti és módszertani kereteinek meghatározásához. Fehér Krisztina a kognitív pszichológiai kísérletek, eszközfonetikai 
mérések, szociolingvisztikai felmérések, valamint a dialektológiai adatgyüjtésekből származó nyelvi anyagok korpusznyelvészeti eszközökkel vizsgált eredményeit megfelelően szintetizálta egy új nyelvtani modellben. A nyelvelsajátításra, nyelvi percepcióra és produkcióra vonatkozó kutatásokra alapozva egy statisztikai alapú, hálózatosan szerveződő analógianyelvtan koncepciója bontakozik ki a könyvben, amely dinamikusságából adódóan kezelni tudja a nyelvi változást és változatosságot. A munka sok tekintetben illeszkedik a funkcionális és kognitív nyelvészeti irányzatok hazai és nemzetközi megközelítéseihez, itt csak két munkát említek azok közül, amelyekkel különösen rokonítható: a TOLCSVAI NAGY GÁBOR szerkesztette Nyelvtan (2017) címü kötetet, valamint JOAN BYBEE fentebb már idézett monográfiáját (2010); a három mű eredményesen egészítheti ki egymást a nyelv müködésének megértésében. Mindezzel együtt elmondható, hogy Fehér Krisztina A nyelv grammatikája címü kötete a nyelvről való tudás útvesztőjében értékes iránymutatást ad.

\section{Irodalom}

BYBEe, JoAn 2010. Language, usage and cognition. Cambridge, Cambridge University Press. https://doi.org/10.1017/CBO9780511750526

HALLIDAY, MiCHAEL A. K. 1978. Language as Social Semiotic, the social interpretation of language and meaning. London, Edward Arnold.

Halliday, Michael A. K. 1994. An Introduction to Functional Grammar. London, Edward Arnold.

LANGACKER, RONALD W. 1987. Foundations of cognitive grammar. 1. Theoretical prerequisites. Stanford, Stanford University Press.

LANGACKER, RONALD W. 2008. Cognitive grammar: A basic introduction. Oxford, Oxford University Press. https://doi.org/10.1093/acprof:oso/9780195331967.001.0001

TOLCSVAI NAGY GÁBOR szerk. 2017. Nyelvtan. Budapest, Osiris Kiadó.

K. MOLNÁR EMESE

ORCID: 0000-0002-2755-8595

Eötvös Loránd Tudományegyetem emesekmolnar@gmail.com 